\title{
Detection of ovine herpesvirus-2 in swine semen, Brazil
}

\author{
Erica Azevedo Costa*, Aline de Marco Viott, Glauber de Souza Machado, Maria Rosa Quaresma Bomfim, \\ Fabiana Magalhães Coelho, Mauricio Resende, Roberto Mauricio Carvalho Guedes
}

From $16^{\text {th }}$ International Symposium on HIV and Emerging Infectious Diseases

Marseille, France. 24-26 March 2010

\section{Background}

Malignant Catarrhal Fever (MCF) is an often lethal viral disease of susceptible biungulates from Bovidae, Cervidae and Suidae subfamilies. Cases of porcine MCF have been associated with direct or indirect contact with sheep, the main reservoir of ovine herpesvirus-2 (OvHV-2). Pigs are terminal hosts and not considered in virus spread. Herein, we described the possible venereal transmission by infected semen in a pig herd.

\section{Methods}

In a breeding herd, it has been observed the occurrence of neurologic signs represented by excitation associated with high fever and abortion in pregnant sows and gilts for the last seven years. The mortality rate of disease ranged up to $5 \%$ of total sow breeding stock per year. Due the elevated biosecurity pattern, the pigs have no previous contact with sheep or any other ruminant. The histopathologic findings from brainstem samples of 5 sows collected from 2004 to 2008 outbreaks were consistent with MCF-like lesions, such as severe lymphocytic meningoencephalitis and necrotizing vasculitis. DNA was extracted from these samples and PCR was performed to detect ovine herpesvirus $2(\mathrm{OvHV}-2)$, pseudorabies and porcine cytomegalovirus.

\section{Results}

The OvHV-2 DNA was detected in 4 paraffin sections of brainstem. No amplification was observed for specific PCR assays for Aujeszky's disease and porcine cytomegalovirus. To confirm the member of MCFV group, one amplicon was sequenced and showed an identity of $99 \%$ with nucleotide sequences of OvHV-2 deposited in

\footnotetext{
* Correspondence: azevedoec@yahoo.com.br

Universidade Federal de Minas Gerais, Belo Horizonte, Brazil
}

the GenBank. In order to find possible virus carrier, blood samples were collected from pregnant sows and breeding boars, being the viral DNA detection in three boars. To investigate the potential mode of OvHV-2 transmission, nasal swabs and semen samples were collected from these infected boars. The OvHV-2 DNA was detected only in semen samples. Two out of 3 semen had $>350$ copy number $/ 2 \mu \mathrm{g}$ of total DNA, suggesting possible shedders. Important to mention that through out this period all infected boars remained clinically healthy.

\section{Discussion}

The combination of these results together with the absence of direct or indirect contact with sheep suggests the possibility of venereal transmission from infected semen to susceptible sows and gilts.

Published: 11 May 2010

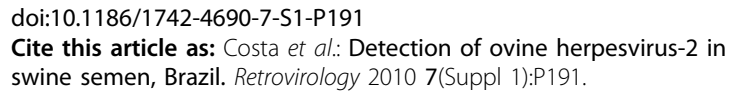

Cite this article as: Costa et al:: Detection of ovine herpesvirus-2 in swine semen, Brazil. Retrovirology 2010 7(Suppl 1):P191.

Submit your next manuscript to BioMed Central and take full advantage of:

- Convenient online submission

- Thorough peer review

- No space constraints or color figure charges

- Immediate publication on acceptance

- Inclusion in PubMed, CAS, Scopus and Google Scholar

- Research which is freely available for redistribution

Submit your manuscript at www.biomedcentral.com/submit
() Biomed Central 